DOI 10.31489/2020M3/96-104

MSC 35N25, 35J67

\author{
A.Ashyralyev ${ }^{1,2,3}$, C.Ashyralyyev ${ }^{4,5}$, V.G.Zvyagin ${ }^{6}$ \\ ${ }^{1}$ Department of Mathematics, Near East University, Nicosia, TRNC, Mersin 10, Turkey \\ ${ }^{2}$ Peoples' Friendship University of Russia (RUDN University), 6 Miklukho-Maklaya St, \\ Moscow 117198 Russian Federation \\ ${ }^{3}$ Institute of Mathematics and Mathematical Modeling, 050010, Almaty, Kazakhstan \\ ${ }^{4}$ Department of Mathematical Engineering, Gumushane University, 29100, Gumushane, Turkey \\ ${ }^{5}$ Department of Computer Technology, TAU, Ashgabat, 744000, Turkmenistan \\ ${ }^{6}$ Voronezh State University, Universitetskaya sq. 1, Voronezh, 394018, Russian Federation \\ (E-mail: allaberen.ashyralyev@neu.edu.tr, charyar@gmail.com,zvg-vsu@mail.ru)
}

\title{
A note on well-posedness of source identification elliptic problem in a Banach space
}

\begin{abstract}
We study the source identification problem for an elliptic differential equation in a Banach space. The exact estimates for the solution of source identification problem in Hölder norms are obtained. In applications, four elliptic source identification problems are investigated. Stability and coercive stability estimates for solution of source identification problems for elliptic equations are obtained.

Keywords: well-posedness, elliptic equations, positivity, coercive stability, source identification, exact estimates, boundary value problem.
\end{abstract}

\section{Introduction}

Several source identification problems for partial differential equations have been extensively investigated by many researchers (see [3,4,8-11,14,15,17-19] and the bibliography herein). Well-posedness of nonclassical boundary value problems for various partial differential and difference equations was established in a number of publications (see [1]-[22] and references therein).

Large number of the source identification problems for an elliptic differential equations can be written as the source identification problem for the second order differential equation

$$
\left\{\begin{array}{l}
-u^{\prime \prime}(t)+A u(t)=f(t)+p, \quad 0<t<1, \\
u(0)=u(1), u^{\prime}(0)=u^{\prime}(1), u(\lambda)=\xi, \lambda \in(0,1)
\end{array}\right.
$$

in an arbitrary Banach space $E$ with a positive operator $A$. Here parameter $p \in E$ and abstract function $u:[0,1] \rightarrow E$ are unknown and element $\xi \in D(A)$ and abstract function $f:[0,1] \rightarrow E$ are given.

Let $E_{1} \subset E$ and $F(E)$ be the Banach space of $E$-valued smooth functions on $[0,1]$. We say that the pair $\{u(t), p\}$ is the solution of the source identification problem (1) in $F(E) \times E_{1}$ if the following conditions are valid:

(i) $p \in E_{1}, u^{\prime \prime}(t) \in F(E), A u(t) \in F(E)$,

(ii) $\{u(t), p\}$ is satisfied the equation and all three conditions of (1).

In the present paper, theorem on well-posedness of the source identification problem (1) in Hölder spaces is established. In applications, stability and coercive stability estimates for solution of the four type of source identification problems for elliptic equations are obtained. 


\section{Stability and coercive stability estimates}

Denote by $C_{01}^{\alpha, \alpha}(E)(0<\alpha<1)$, the Banach space obtained by completion of the set of $E$-valued smooth functions $\varphi(t)$ defined on $[0,1]$ with values in $E$ in the norm

$$
\|\varphi\|_{C_{01}^{\alpha, \alpha}(E)}=\|\varphi\|_{C(E)}+\sup _{0 \leq t<t+\tau \leq 1} \tau^{-\alpha}(1-t)^{\alpha}(t+\tau)^{\alpha}\|\varphi(t+\tau)-\varphi(t)\|_{E},
$$

where $C(E)$ is the Banach space of all continuous functions $\varphi(t)$ defined on $[0,1]$ with values in $E$ equipped with the norm

$$
\|\varphi\|_{C(E)}=\max _{0 \leq t \leq 1}\|\varphi(t)\|_{E} .
$$

Assume that $v(t)$ is the solution of the nonlocal boundary value problem

$$
\left\{\begin{array}{l}
-v^{\prime \prime}(t)+A v(t)=f(t), 0<t<1, \\
v(0)=v(1), v^{\prime}(0)=v^{\prime}(1) .
\end{array}\right.
$$

Then, for the solution of problem (1) we have the following formulas

$$
\begin{gathered}
u(t)=v(t)+A^{-1} p, \\
p=A \xi-A v(\lambda) .
\end{gathered}
$$

Therefore, the following algorithm can be used to find the solution of problem (1):

(1) Find the solution $v(t)$ of nonlocal boundary value problem (2).

(2) Use (4) to obtain the source element $p$ of source identification problem (1).

(3) Applying (3), obtain the solution $u(t)$ of source identification problem (1).

It is known that the operator $B=A^{\frac{1}{2}}$ is the strongly positive operator for any positive operator $A$. Therefore, the operator $-B$ will be a generator of an analytic semigroup $\exp -t B(t \geq 0)$ with exponentially decreasing norm (see [7]), when $t \rightarrow \infty$, i.e. there exist some $M(B) \in[1,+\infty)$, $\alpha(B) \in(0,+\infty)$ such that the following estimates

$$
\begin{gathered}
\|\exp (-t B)\|_{E \rightarrow E} \leq M(B) \exp (-\alpha(B) t), \\
\|t B \exp (-t B)\|_{E \rightarrow E} \leq M(B) \exp (-\alpha(B) t)(t>0), \\
\|T\|_{E \rightarrow E} \leq M(B)(1-\exp (-\alpha(B)))^{-1}
\end{gathered}
$$

are satisfied. Here $T=(I-\exp (-B))^{-1}$.

The solution of direct problem (2) is defined by (formula (1.7) [1])

$$
\begin{aligned}
& v(t)=\frac{1}{2} B^{-1} T \exp (-(1-t) B) \int_{0}^{1} \exp (-s B) f(s) d s \\
& +\frac{1}{2} B^{-1} \int_{0}^{t} \exp (-(t-s) B) f(s) d s+\frac{1}{2} B^{-1} \int_{t}^{1} \exp ((t-s) B) f(s) d s \\
& +\frac{1}{2} B^{-1} T \exp (-t B) \int_{0}^{1} \exp (-(1-s) B) f(s) d s .
\end{aligned}
$$


From (4) and (8), it follows that

$$
\begin{aligned}
& p=A \xi-\frac{1}{2} B T \exp (-(1-\lambda) B) \int_{0}^{1} \exp (-s B) f(s) d s \\
& -\frac{1}{2} B \int_{0}^{\lambda} \exp (-(\lambda-s) B) f(s) d s-\frac{1}{2} B \int_{\lambda}^{1} \exp ((\lambda-s) B) f(s) d s \\
& -\frac{1}{2} B T \exp (-B \lambda) \int_{0}^{1} \exp (-(1-s) B) f(s) d s .
\end{aligned}
$$

Finally, by using formulas (8), (3) and (9), we can obtain $u(t)$.

Now, we formulate result on well-posedness of the source identification problem (1) in the space $C_{01}^{\alpha, \alpha}(E)$.

Theorem 1. Assume that $\xi \in D(A)$ and $f(t) \in C_{01}^{\alpha, \alpha}(E), 0<\alpha<1$. For the solution $\{u(t), p\}$ of the source identification problem (1) the following stability inequality

$$
\|u\|_{C(E)}+\left\|A^{-1} p\right\|_{E} \leq M\left[\|\xi\|_{E}+\|f\|_{C(E)}\right]
$$

and coercive inequality

$$
\left\|u^{\prime \prime}\right\|_{C_{01}^{\alpha, \alpha}(E)}+\|A u\|_{C_{01}^{\alpha, \alpha}(E)}+\|p\|_{E} \leq M\left[\|A \xi\|_{E}+\frac{1}{\alpha(1-\alpha)}\|f\|_{C_{01}^{\alpha, \alpha}(E)}\right],
$$

hold, where $M$ is independent of $\alpha, \xi$ and $f(t)$.

The proof of Theorem 1 is based on the formula (3) and estimates (5) and (7) on the Theorem on well-posedness of the nonlocal boundary value problem (2) [1].

Note that same results can be established for the solutions of the general source identification problems

$$
\left\{\begin{array}{l}
-u^{\prime \prime}(t)+A u(t)=f(t)+p, \quad 0<t<1, \\
u(0)=\sum_{j=1}^{N} a_{j} u\left(t_{j}\right)+\varphi, u^{\prime}(0)=u^{\prime}(1)+\psi, u(\lambda)=\xi, \lambda \in(0,1),
\end{array}\right.
$$

where $0<t_{1}<\ldots<t_{N} \leq 1$, if the operator

$$
I-e^{-2 B}-\sum_{j=1}^{N} a_{j}\left(e^{-t_{j} B}-e^{-\left(2-t_{j}\right) B}-e^{-\left(1-t_{j}\right) B}+e^{-\left(1+t_{j}\right) B}\right)
$$

has a bounded inverse in $E$ and

$$
\left\{\begin{array}{l}
-u^{\prime \prime}(t)+A u(t)=f(t)+p, \quad 0<t<1, \\
u(0)=u(1)+\varphi, u^{\prime}(0)=\sum_{j=1}^{N} a_{j} u^{\prime}\left(s_{j}\right)+\psi, u(\lambda)=\xi, \lambda \in(0,1),
\end{array}\right.
$$

where $0<s_{1}<\ldots<s_{N} \leq 1$, if the operator

$$
\left(I-e^{-B}\right)^{2}-\sum_{j=1}^{N} a_{j}\left(e^{-s_{j} B}+e^{-\left(2-s_{j}\right) B}-e^{-\left(1-s_{j}\right) B}-e^{-\left(1+s_{j}\right) B}\right)
$$

has a bounded inverse in $E$. 


\section{Applications}

In this section, we consider the applications of Theorem 1. First, we study the source identification problem for the two dimensional elliptic differential equation with nonlocal boundary conditions

$$
\left\{\begin{array}{l}
-\frac{\partial^{2} u(t, x)}{\partial t^{2}}-a(x) \frac{\partial^{2} u(t, x)}{\partial x^{2}}+\delta u(t, x)=f(t, x)+p(x), \\
0<t<1,0<x<l, \\
u(0, x)=u(1, x), u_{t}(0, x)=u_{t}(1, x), u(\lambda, x)=\xi(x), 0 \leq x \leq l, \\
u(t, 0)=u(t, l), \quad u_{x}(t, 0)=u_{x}(t, l), \quad 0 \leq t \leq 1,
\end{array}\right.
$$

where $a(x), \xi(x)$ and $f(t, x)$ are given sufficiently smooth functions and $a(x)>0,0<\lambda<1, \delta>0$ is a sufficiently large number. Assume that all compatibility conditions are satisfied.

We introduce the Banach spaces $C^{\beta}[0, l] \quad(0<\beta<1)$ of all continuous functions $\varphi(x)$ satisfying a Hölder condition for which the following norms are finite

$$
\|\varphi\|_{C^{\beta}[0, l]}=\|\varphi\|_{C[0, l]}+\sup _{0 \leq x<x+\tau \leq l} \frac{|\varphi(x+\tau)-\varphi(x)|}{\tau^{\beta}},
$$

where $C[0, l]$ is the space of the all continuous functions $\varphi(x)$ defined on $[0, l]$ with the usual norm

$$
\|\varphi\|_{C[0, l]}=\max _{0 \leq x \leq l}|\varphi(x)| .
$$

Theorem 2. For the solution of the source identification problem (12) the following stability and coercive stability estimates hold:

$$
\begin{aligned}
& \|u\|_{C\left(C^{\beta}[0, l]\right)} \leq M(\beta)\left[\|\xi\|_{C^{\beta}[0, l]}+\|f\|_{C\left(C^{\beta}[0, l]\right)}\right] \\
& \|u\|_{C_{01}^{2+\alpha, \alpha}\left(C^{\beta}[0, l]\right)}+\|u\|_{C_{01}^{\alpha, \alpha}\left(C^{\beta+2}[0, l]\right)}+\|p\|_{C^{\beta}[0, l]} \\
& \leq \frac{M(\beta)}{\alpha(1-\alpha)}\|f\|_{C_{01}^{\alpha, \alpha}\left(C^{\beta}[0, l]\right)}+M(\beta)\|\xi\|_{C^{\beta+2}[0, l]},
\end{aligned}
$$

where $M(\beta)$ is independent of $\alpha, \xi(x)$ and $f(t, x), 0<\alpha<1,0<\beta<1$.

The proof of Theorem 2 is based on the Theorem 1 and the positivity of the elliptic operator $A$ in $C^{\beta}[0, l][7]$.

Second, we investigate the source identification problem on the range $\left\{0 \leq t \leq 1, x \in R^{n}\right\}$

$$
\left\{\begin{array}{l}
-u_{t t}(t, x)+\sum_{|l|=2 m} a_{l}(x) \frac{\partial^{|l|}}{\partial x_{1}^{l_{1}} \ldots \partial x_{n}^{l_{n}}} u(t, x)+\delta u(t, x)=f(t, x)+p(x), \\
0<t<1, x \in R^{n}, \\
u(0, x)=u(1, x), u_{t}(0, x)=u_{t}(1, x), u(\lambda, x)=\xi(x), x \in R^{n}
\end{array}\right.
$$

for the $2 m$-order multidimensional elliptic equation, where $a_{l}(x)\left(l=\left(l_{1}, \ldots, l_{n}\right),|l|=0, \ldots, 2 m\right)$ and $\xi(x)$ are known sufficiently smooth functions, $a_{l}(x)>0$, and $0<\lambda<1, \delta>0$ are given real numbers. Assume that all compatibility conditions are satisfied and the symbol

$$
F^{x}(\zeta)=\sum_{|l|=2 m} a_{l}(\zeta)\left(i \zeta_{1}\right)^{l_{1}} \ldots\left(i \zeta_{n}\right)^{l_{n}}, \zeta=\left(\zeta_{1}, \ldots, \zeta_{n}\right) \in R^{n}
$$


of the differential operator

$$
F^{x}=\sum_{|l|=2 m} a_{l}(\zeta) \frac{\partial^{|l|}}{\partial x_{1}^{l_{1}} \ldots \partial x_{n}^{l_{n}}}
$$

acting on functions in the space $R^{n}$, satisfies the inequalities

$$
0 \leq M_{1}|\zeta|^{2 m} \leq(-1)^{m} F^{x}(\zeta) \leq M_{2}|\zeta|^{2 m}<\infty
$$

for $\zeta \neq 0$.

Theorem 3. For the solution of the source identification problem (13) the following stability and coercive stability estimates are satisfied:

$$
\begin{gathered}
\|u\|_{C\left(C^{\mu}\left(R^{n}\right)\right)} \leq M(\mu)\left[\|\xi\|_{C^{\mu}\left(R^{n}\right)}+\|f\|_{C\left(C^{\mu}\left(R^{n}\right)\right)}\right] \\
\|u\|_{C_{01}^{2+\alpha, \alpha}\left(C^{\mu}\left(R^{n}\right)\right)}+\sum_{|l|=2 m}\left\|\frac{\partial^{|l|} u}{\partial x_{1}^{l_{1} \ldots \partial x_{n}^{l_{n}}}}\right\|_{C_{01}^{\alpha, \alpha}\left(C^{\mu}\left(R^{n}\right)\right)}+\|p\|_{C^{\mu}\left(R^{n}\right)} \\
\leq \frac{M(\mu)}{\alpha(1-\alpha)}\|f\|_{C_{01}^{\alpha, \alpha}\left(C^{\mu}\left(R^{n}\right)\right)}+M(\mu) \sum_{|l|=2 m}\left\|\frac{\partial^{|l|} \xi}{\partial x_{1}^{l_{1}} \ldots \partial x_{n}^{l_{n}}}\right\|_{C^{\mu}\left(R^{n}\right)}
\end{gathered}
$$

where $M(\mu)$ is independent of $\alpha, \xi(x)$ and $f(t, x), 0<\alpha<1,0<\mu<1$.

The proof of Theorem 3 is based on the Theorem 1 and the positivity of the elliptic operator $A^{x}$ in $C^{\mu}\left(R^{n}\right)$ [7] and the coercivity estimate for an operator $A^{x}$ in $C^{\mu}\left(R^{n}\right)$ [8].

Third, let $\Omega=(0,1)^{n}$ be the open cube in $R^{n}$ with suitable boundary $S, \bar{\Omega}=\Omega \cup S$. In $[0,1] \times \Omega$, we study the source identification problem

$$
\left\{\begin{array}{l}
-u_{t t}(t, x)-\sum_{k=1}^{n} a_{k}(x) u_{x_{k} x_{k}}(t, x)+\delta u(t, x)=f(t, x)+p(x), \\
x=\left(x_{1}, \ldots, x_{n}\right) \in \Omega, 0<t<1 \\
u(0, x)=u(1, x), u_{t}(0, x)=u_{t}(1, x), u(\lambda, x)=\xi(x), x \in \bar{\Omega} \\
u(t, x)=0,0 \leq t \leq 1, x \in S
\end{array}\right.
$$

for the multidimensional elliptic equation. Here $a_{r}(x)(x \in \Omega)$ and $\varphi(x), \psi(x), \xi(x)(x \in \bar{\Omega})$ are given sufficiently smooth functions, and $0<\lambda<T, \delta>0$ are known numbers. Assume that all compatibility conditions are satisfied.

Denote by $C_{01}^{\beta}(\bar{\Omega})\left(\beta=\left(\beta_{1}, \ldots, \beta_{n}\right), \beta_{i}, 1 \leq i \leq n\right)$, the Banach spaces of continuous functions satisfying a Hölder condition with weight $x_{k}^{\beta_{k}}\left(1-x_{k}-h_{k}\right)^{\beta_{i}}, 0 \leq x_{k}<x_{k}+h_{k} \leq 1,1 \leq k \leq n$ and the indicator $\beta$ which equipped with the corresponding norm

$$
\begin{aligned}
& \|f\|_{C_{01}^{\beta}(\bar{\Omega})}=\|f\|_{C(\bar{\Omega})} \\
& +\sup _{0 \leq x_{k}<x_{k}+h_{k} \leq 1,}|f(x+h)-f(x)| \prod_{k=1}^{n}\left(\frac{x_{k}}{h_{k}}\right)^{\beta_{k i}}\left(1-x_{k}-h_{k}\right)^{\beta_{k}} .
\end{aligned}
$$

It is well known that the differential expression

$$
A^{x} u=-\sum_{k=1}^{n} a_{k} u_{x_{k} x_{k}}+\delta u
$$


defines a positive operator $A^{x}$ acting on $C_{01}^{\beta}(\bar{\Omega})$ with domain $D\left(A^{x}\right) \subset C_{01}^{2+\beta}(\bar{\Omega})$ and satisfying the boundary condition $u=0$ on $S$.

Theorem 4. For the solution of the source identification problem (15) the following stability and coercive stability estimates hold

$$
\begin{gathered}
\|u\|_{C\left(C_{01}^{\mu}(\bar{\Omega})\right)} \leq M(\mu)\left[\|f\|_{C\left(C_{01}^{\mu}(\bar{\Omega})\right)}+\|\xi\|_{C_{01}^{\mu}(\bar{\Omega})}\right], \\
\|u\|_{C_{01}^{2+\alpha, \alpha}\left(C_{01}^{\mu}(\bar{\Omega})\right)}+\sum_{k=1}^{n}\left\|u_{x_{k} x_{k}}\right\|_{C_{0 T}^{\alpha, \alpha}\left(C_{01}^{\mu}(\bar{\Omega})\right)}+\|p\|_{C_{01}^{\mu}(\bar{\Omega})} \\
\leq \frac{M(\mu)}{\alpha(1-\alpha)}\|f\|_{C_{0 T}^{\alpha, \alpha}\left(C_{01}^{\mu}(\bar{\Omega})\right)}+M(\mu)\|\xi\|_{C_{01}^{\mu+2}(\bar{\Omega})}, \\
0<\alpha<1, \mu=\left(\mu_{1}, \ldots, \mu_{n}\right), 0<\mu_{i}<1,1 \leq i \leq n,
\end{gathered}
$$

where $M(\mu)$ is independent of $\alpha, \xi(x)$ and $f(t, x)$.

Fourth, in $[0,1] \times \Omega$, we consider the source identification problem

$$
\left\{\begin{array}{l}
-u_{t t}(t, x)-\sum_{k=1}^{n} a_{k}(x) u_{x_{k} x_{k}}(t, x)+\delta u(t, x)=f(t, x)+p(x), \\
x \in \Omega, 0<t<1, \\
u(0, x)=u(1, x), u_{t}(0, x)=u_{t}(1, x), u(\lambda, x)=\xi(x), x \in \bar{\Omega}, \\
\frac{\partial}{\partial \vec{n}} u(t, x)=0,0 \leq t \leq 1, x \in S
\end{array}\right.
$$

for the multidimensional elliptic equation. Assume that all compatibility conditions are satisfied. The differential expression (16) defines a positive operator $A^{x}$ acting on $C_{01}^{\beta}(\bar{\Omega})$ with domain

$D\left(A^{x}\right) \subset C_{01}^{2+\beta}(\bar{\Omega})$ and satisfying the boundary condition $\frac{\partial u}{\partial \vec{n}}=0$ on $S$. Therefore, by using Theorem 1 , we can get the following result.

Theorem 5. For the solution of the source identification problem (19) the stability and coercive stability estimates (17) and (18) respectively are valid.

\section{Conclusion}

In the present paper, the well-posedness of the source identification problem for the abstract elliptic equation in Banach spaces is investigated. The exact estimates for the solution of this problem in Hölder norms are established. In future investigation, absolute stable difference schemes for approximately solution of the source identification problem for elliptic differential equations will be constructed and investigated.

\section{Acknowledgement}

The publication has been prepared with the support of the "RUDN University Program 5-100".

\section{References}

1 Ashyralyev A. On well-posedness of the nonlocal boundary for elliptic equations / A. Ashyralyev // Numer. Funct. Anal. Optim. - 2003. - 24. - P. 1-15.

2 Ashyralyev A. A note on the Bitsadze-Samarskii type nonlocal boundary value problem in a Banach space / A. Ashyralyev // J.Math. Anal.Appl. - 2008. - 344. - P. 557-573. 
3 Ashyralyev A. On the problem of determining the parameter of a parabolic equation / A. Ashyralyev // Ukrainian Mathematical Journal - 2011. - 62. - P. 1397-1408.

4 Ashyralyev A. On well-posedness of nonclassical problems for elliptic equations / A. Ashyralyev, F.S.O. Tetikoglu // Math. Methods Appl. Sci. - 2014. - 37. P. 2663-2676.

5 Ashyralyev A. On the problem of determining the parameter of an elliptic equation in a Banach space / A. Ashyralyev, C. Ashyralyyev // Nonlinear Anal. Model. Control. - 2014. - 19. No. 3. - P. 350-366.

6 Ashyralyev A. New Difference Schemes for Partial Differential Equations, Operator Theory Advances and Applications / A. Ashyralyev, P.E. Sobolevskii. - Birkhäuser Verlag, Basel, Boston, Berlin, 2004. - 444 p.

7 Ashyralyev A. Well-Posedness of Parabolic Difference Equations, Operator Theory Advances and Applications / A. Ashyralyev, P.E. Sobolevskii. - Birkhäuser Verlag, Basel, Boston, Berlin, 1994. $-364 \mathrm{p}$.

8 Ashyralyyev C. Numerical solution to Bitsadze-Samarskii type elliptic overdetermined multipoint NBVP / C. Ashyralyyev // Bound. Value Probl. - 2017. - 74. - P. 1-22.

9 Ashyralyyev, C. Approximate solution for an inverse problem of multidimensional elliptic equation with multipoint nonlocal and Neumann boundary conditions / C. Ashyralyyev, G. Akyuz, M. Dedeturk // Electron. J. Differential Equations. - 2017. - 197. - P. 1-16.

10 Ashyralyyev C. Stability estimates for solution of Neumann type overdetermined elliptic problem / C. Ashyralyyev // Numer. Funct. Anal. Optim. - 2017. - 38. - No.10. - P. 1226-1243.

11 Ashyralyyev C. Well-posedness of Neumann-type elliptic overdetermined problem with integral condition / C. Ashyralyyev, A. Cay // AIP Conference Proceedings. - 1997. - No. 020026.

12 Avalishvili G. On a nonlocal problem with integral boundary conditions for a multidimensional elliptic equation / G. Avalishvili, M. Avalishvili, D. Gordeziani // Applied Mathematical Letters. - 2011. - 24. - P. 566-571.

13 Berikelashvili G. On the convergence rate of a difference solution of the Poisson equation with fully nonlocal constraints / G. Berikelashvili, N. Khomeriki // Nonlinear Anal. Model. Control. - 2014. - 19. - P. 367-381.

14 Kabanikhin S.I. Inverse and Ill-Posed Problems: Theory and Applications / S.I. Kabanikhin. Walter de Gruyter, Berlin, 2011.

15 Kabanikhin S.I. Theory and numerical methods for solving inverse and ill-posed problems / S.I. Kabanikhin, M.A. Shishlenin // J.Inverse Ill-Posed Probl. - 2019. — 27. - P. 453-456

16 Kozhanov A.I. Nonlocal problems with integral conditions for elliptic equations / A.I. Kozhanov // Complex variables and elliptic equations. - 2019. - 64. - P. 741-752.

17 Orlovsky D.G. Inverse problem for elliptic equation in a Banach space with Bitsadze-Samarsky boundary value conditions / D.G. Orlovsky // J.Inverse Ill-Posed Probl. - 2013. - 21. - P. 141157.

18 Orlovsky D.G. The approximation of Bitzadze-Samarsky type inverse problem for elliptic equations with Neumann conditions / D.G. Orlovsky, S.I. Piskarev // Contemporary Analysis and Applied Mathematics. - 2013. - 1. - No. 2. - P. 118-131.

19 Samarskii A.A. Numerical Methods for Solving Inverse Problems of Mathematical Physics, Inverse and Ill-posed Problems Series / A.A. Samarskii, P.N. Vabishchevich. - Walter de Gruyter, Berlin, New York, 2007.

20 Sapagovas M. On a nonlocal problem with integral boundary conditions for a multidimensional elliptic equation / M. Sapagovas, V. Griškonien, O. Štikonien // Bound. Value Probl. - 2019. 94. 
21 Sapagovas M. Application of m-matrices to numerical investigation of a nonlinear elliptic equation with an integral condition / M. Sapagovas, V. Griškonien, O. Štikonien // Nonlinear Anal. Model. Control. - 2017. - 22. - P. 489-504.

22 Skubachevskii A.L. On a nonlocal problem with integral boundary conditions for a multidimensional elliptic equation / A.L. Skubachevskii // Russian Mathematical Surveys. - 2016. - 71. P. 801-906.

А. Ашыралыев, Ч. Ашыралыев, В.Г. Звягин

\title{
Банах кеңістігінде дереккөзді сәйкестендіруде эллипстік есептің корректілігі туралы ескерту
}

\begin{abstract}
Банах кеңістігінде эллипстік дифференциалдық теңдеу үшін дереккөзді сәйкестендіру мәселесі қарастырылған. Хелдер нормасында дереккөздерді сәйкестендіру есебін шешу үшін дәл бағамы алынды. Қосымшаларда дереккөзді сәйкестендірудің төрт эллипстік есебі зерттелген. Эллипстік теңдеу үшін дереккөздерді сәйкестендіру есебін шешу үшін мәжбүрлі орнықтылық және орнықтылық бағамы алынған.
\end{abstract}

Kiлm сөздер: корректілігі, эллипстік теңдеу, позитивті, мәжбүрлі орнықтылық, дереккөзді сәйкестендіру, дәл бағамы, шеттік есеп.

А. Ашыралыев, Ч. Ашыралыев, В.Г. Звягин

\section{Замечание о корректности эллиптической задачи идентификации источника в банаховом пространстве}

\begin{abstract}
Исследована проблема идентификации источника для эллиптического дифференциального уравнения в банаховом пространстве. Получены точные оценки для решения задачи идентификации источника в нормах Хелдера. В приложениях исследованы четыре эллиптических задачи идентификации источника. Получены оценки устойчивости и коэрцитивной устойчивости для решения задач идентификации источника для эллиптических уравнений.
\end{abstract}

Ключевые слова: корректность, эллиптические уравнения, позитивность, коэрцитивная устойчивость, идентификация источника, точные оценки, краевая задача.

\section{References}

1 Ashyralyev, A. (2003). On well-posedness of the nonlocal boundary for elliptic equations. Numer. Funct. Anal. Optim., 24, 1-15.

2 Ashyralyev, A.(2008). A note on the Bitsadze-Samarskii type nonlocal boundary value problem in a Banach space. J. Math. Anal. Appl., 344, 557-573.

3 Ashyralyev, A. (2011). On the problem of determining the parameter of a parabolic equation. Ukrainian Mathematical Journal, 62, 1397-1408.

4 Ashyralyev, A., \& Ashyralyyev, C. (2014). On the problem of determining the parameter of an elliptic equation in a Banach space. Nonlinear Anal. Model. Control. 19, 3 350-366.

5 Ashyralyev, A., \& Tetikoglu, F.S.O. (2014). On well-posedness of nonclassical problems for elliptic equations. Math. Methods Appl. Sci., 37, 2663-2676. 
6 Ashyralyev, A., \& Sobolevskii, P.E. (2004). New Difference Schemes for Partial Differential Equations, Operator Theory Advances and Applications. Birkhäuser Verlag, Basel, Boston, Berlin.

7 Ashyralyev, A., \& Sobolevskii, P.E. (1994). Well-Posedness of Parabolic Difference Equations, Operator Theory Advances and Applications. Birkhäuser Verlag, Basel, Boston, Berlin.

8 Ashyralyyev, C. (2017). Numerical solution to Bitsadze-Samarskii type elliptic overdetermined multipoint NBVP. Bound. Value Probl., 2017, 74, 1-22.

9 Ashyralyyev, C., Akyuz, G., \& Dedeturk, M. (2017). Approximate solution for an inverse problem of multidimensional elliptic equation with multipoint nonlocal and Neumann boundary conditions, Electron. J. Differential Equations, 2017, 197, 1-16.

10 Ashyralyyev, C. (2017). Stability estimates for solution of Neumann type overdetermined elliptic problem. Numer. Funct. Anal. Optim., 38, 10 1226-1243.

11 Ashyralyyev, C., \& Cay, A. (2018). Well-posedness of Neumann-type elliptic overdetermined problem with integral condition. AIP Conference Proceedings, 1997, 020026.

12 Avalishvili, G., Avalishvili, M., \& Gordeziani, D. (2011). On a nonlocal problem with integral boundary conditions for a multidimensional elliptic equation. Applied Mathematical Letters, 24, 566-571.

13 Berikelashvili, G., \& Khomeriki, N. (2014). On the convergence rate of a difference solution of the Poisson equation with fully nonlocal constraints. Nonlinear Anal. Model. Control., 19, 367-381.

14 Kabanikhin, S. I. (2011). Inverse and ill-posed problems: theory and applications. Walter de Gruyter, Berlin.

15 Kabanikhin, S.I., \& Shishlenin, M.A. (2019). Theory and numerical methods for solving inverse and ill-posed problems. J.Inverse Ill-Posed Probl., 27 453-456.

16 Kozhanov, A.I. (2019). Nonlocal problems with integral conditions for elliptic equations. Complex variables and elliptic equations, 64, 741-752.

17 Orlovsky, D.G. (2013). Inverse problem for elliptic equation in a Banach space with BitsadzeSamarsky boundary value conditions J.Inverse Ill-Posed Probl., 21, 141-157.

18 Orlovsky, D.G., \& Piskarev, S.I. (2013). The approximation of Bitsadze-Samarsky type inverse problem for elliptic equations with Neumann conditions Contemporary Analysis and Applied Mathematics, 1. No. 2, 118-131.

19 Samarskii, A.A., \& Vabishchevich, P.N. (2007). Numerical Methods for Solving Inverse Problems of Mathematical Physics, Inverse and Ill-posed Problems Series. Walter de Gruyter, Berlin, New York.

20 Sapagovas, M., Griškonien, V., \& Štikonien, O. (2019). On a nonlocal problem with integral boundary conditions for a multidimensional elliptic equation. Bound. Value Probl., 94.

21 Sapagovas, M., Griškonien, V., \& Štikonien, O. (2017). Application of m-matrices to numerical investigation of a nonlinear elliptic equation with an integral condition. Nonlinear Anal. Model. Control., 22, 489-504.

22 Skubachevskii, A.L. (2016). On a nonlocal problem with integral boundary conditions for a multidimensional elliptic equation Russian Mathematical Surveys, 71, 801-906. 